\title{
Tasa-arvo- ja yhdenvertaisuusasiantuntijuuden affektiivinen tyyli palvelutaloudessa
}

\begin{abstract}
Abstrakti
口. Tarkastelemme tässä artikkelissa työelämän tasa-arvo- ja yhdenvertaisuus asiantuntijuuden affektiivisia vaatimuksia. Tarkastelumme kohteena on kaksivuotinen tasa-arvo- ja yhdenvertaisuusasiantuntijakoulutus. Olemme kiinnostuneita siitä, miten projektimuotoisessa koulutuksessa tullaan tasa-arvo- ja yhdenvertaisuusasiantuntijaksi ja millaista palvelutalouden viitekehyksessä rakentuvaa affektiivista tyyliä se edustaa. Artikkelin kuljeskellen tuotettu aineisto muodostuu asiantuntijakoulutukseen osallistuneiden opiskelijoiden haastatteluista ja oppimispäiväkirjoista sekä havaintomuistiinpanoistamme. Tulokset osoittavat, että negatiivisten affektien välttäminen ja neutraaliuden tavoittelu olivat investointeja 'oikeanlaisiin' tasa-arvoasiantuntijuuden tekemisen tapoihin. Nämä investoinnit johtivat affektiiviseen tyyliin, jossa painottuivat sujuva ja konfliktiton vuorovaikutus sekä etukäteen harjoitellut tekniikat ja argumentit. Koulutuksen tuottama asiantuntemus oli näennäisesti neutraalia, mutta osoittautui valkoiseksi, binaarisesti sukupuolittuneeksi tasa-arvofeminismiksi. Markkinatalouden tasa-arvotyössä, jossa asiantuntijoiden tulee tarjota palveluitaan mahdollisimman monille, liian henkilökohtaisena tai radikaalina näyttäytyvä affektiivinen tyyli on riski legitiimiksi asiantuntijaksi tulemiselle.
\end{abstract}

\section{Johdanto}

Suomessa tasa-arvon ja yhdenvertaisuuden edistäminen on ollut perinteisesti osa valtiollista tasa-arvo- ja hyvinvointipolitiikkaa. Tällä niin kutsulla valtiofeminismillä viitataan toisaalta julkishallinnon ja valtiollisten toimijoiden keskeiseen asemaan tasa-arvon edistämisessä, toisaalta naisjärjestöjen vakiintuneeseen asemaan tasa-arvopolitiikassa ja niiden valtiolta saamaan toiminnan tukeen. (Ikävalko 2016, 25; Mazur \& McBride Stetson 1995, 277-280.) Julkisten palveluiden markkinoitumisen myötä liiketaloudellinen ajattelu ja projektit ovat läpäisseet hyvinvointipalvelusektorin ja nousseet keskeisiksi myös voittoa tavoittelematto- mien, ei-kaupallisten hyvinvointipalveluiden tuottamisessa (Brunila 2009, 5; Ikävalko 2016, 29). Tämän seurauksena tasa-arvopolitiikka ja -työ ovat kytkeytyneet yhä tiiviimmin osaksi palvelutaloutta. Kehitys on osa laajempaa julkisen sektorin ja palveluiden toimintaa ja järjestämistä koskevaa muutosta (esim. Julkunen 2017), mikä näkyy muun muassa markkinaehtoisten mallien lisääntymisenä julkisen sektorin palveluiden tuottamisessa. Palveluita, jotka eivät perinteisesti ole orientoituneet voiton tavoitteluun, tuotetaan yhä enenevissä määrin erilaisia projekti- ja verkostoyhteiskunnan resursseja hyödyntäen (Brunila 2009; Holli 2003; Holli \& Kantola 2007; Ikävalko 2016; Raevaara 2005; Ylöstalo 2012). Tasa-arvotyön yhteiskun- 
nallisena uudelleenorganisoimisen tapana projektit ovat tuoneet tasa-arvotyön piiriin liiketaloudelle tyypillisen tuotteistamista, brändejä ja asiakkuuksia korostavan puhetavan, jossa tasa-arvon edistämispyrkimykset kehystetään yhä useammin tuottavuutta ja tehokkuutta korostavin argumentein (esim. Ikävalko 2016; Kantola \& Squires 2012).

Tasa-arvotyön institutionaalinen asema Suomessa on ollut perinteisesti heikko, ja tasaarvopolitiikalla ja -työllä on ollut usein välineellinen arvo muiden yhteiskunnallisten ja poliittisten intressien palvelemisessa (Brunila 2009). Toiminnan puutteellinen legitimiteetti on johtanut siihen, että tasa-arvotoimijat joutuvat usein hankkimaan oikeutuksen ja edellytykset toiminnalleen jatkuvien projektirahoitusten muodossa sekä myymällä asiantuntijuuttaan toisinaan vastahakoisillekin viranomaisille ja yrityksille. Tasa-arvotyön aseman vakiinnuttamiseksi ja arvostuksen lisäämiseksi toiminnan jatkuvuutta on pyritty varmistamaan korostamalla tasa-arvotyötä professiona eli erityistä ammattitaitoa ja asiantuntemusta edellyttävänä työnä (esim. Brunila 2009; Henriksson \& Wrede 2004). Tasa-arvotyö professiona on asiantuntijuutta, joka edellyttää tasa-arvon tarpeellisuuden jatkuvaa artikuloimista sekä erilaisten tekniikoiden ja neuvottelutapojen hallintaa vaihtelevissa ympäristöissä. Työkalujen soveltamisen lisäksi asiantuntijuuden osaamisalueita ovat erilaisten instituutioiden ja organisaatioiden päätöksenteon tuntemus sekä pedagoginen ja markkinointija myyntiosaaminen. Tasa-arvotyössä saavutetut voitot ovat pieniä, ja lainsäädännön toimeenpanossa on edelleen ongelmia, vaikka tuki tasa-arvotyölle on etenkin 2000-luvulla vankistunut. (Holli \& Kantola 2007; Saari 2016.)

Kysymme tässä artikkelissa, miten projektimuotoisessa koulutuksessa tullaan tasa-arvoja yhdenvertaisuusasiantuntijaksi ja millaista palvelutalouden viitekehyksessä rakentuvaa affektiivista tyyliä se edustaa. Tasa-arvotyössä asiantuntijan ruumis ei ole vain työväline vaan osa myytävää tuotetta ja palvelua eikä työtä ole siten mahdollista irrottaa tasa-arvotyön tekijöistä ja heidän ruumiillisesta olemuksestaan. Palvelutalouden ruumistaitoja edellyttävänä asiantuntijuutena (esim. Parviainen 2011; Valkonen \& Valkonen 2014) tasa-arvotyö on siten myös toimintaa, jossa tasa-arvotyön tavoitteista ja merkityksestä käydään jatkuvaa, affektiivisesti latautunutta kamppailua ja neuvotteluja. Affektin käsite auttaa jäsentämään tasa-arvotyöhön liittyvää asiantuntijuutta ja sen toisinaan ristiriitaisia muotoja ja ilmentymiä (esim. Elomäki, Kantola, Koivunen \& Ylöstalo 2016; Mannevuo 2015; Pedwell \& Whitehead 2012). Käsitteen kautta on mahdollista tavoittaa tasa-arvotyön ja -asiantuntijuuden sosiaalisia ja kulttuurisia ulottuvuuksia; niitä tapoja, joilla affektit ruumiillisina merkityksenannon muotoina kietoutuvat kulttuurisiin, historiallisiin ja sosiaalisiin tasaarvotyön tekemisen tapoihin ja diskursseihin.

Tarkastelumme kohteena on yliopistossa toteutettu projektimuotoinen, kaksivuotinen tasa-arvo- ja yhdenvertaisuusasiantuntijakoulutus, jossa muiden asioiden ohella harjoiteltiin asiantuntijan oikeanlaista affektiivista tyyliä. Koulutus päättyi maaliskuussa 2019. Vastaavaa koulutusta ei ole ollut Suomessa aiemmin tarjolla.

\section{Affektit tasa-arvotyön kulttuuristen erojen ja hierarkioiden merkitsijöinä}

Tässä artikkelissa puhumme sekä ruumiiden affektiivisesta hierarkiasta, että affektien ja tunteiden kulttuurisesta hierarkiasta. Kinnusen ja Parviaisen (2016) mukaan työruumiin toivottavat ominaisuudet perustuvat eri ruumillisuuksien ja ruumiin piirteiden, kuten sukupuolen, luokan, etnisen taustan ja kyvykkyyden kulttuuriseen hierarkiaan ja niiden affektiiviseen latautuneisuuteen. Tasa-arvotyön käytännöissä asiantuntijuuden kulttuuriset merkitykset ja niiden hierarkkiset arvostukset ja normatiivisuudet piirtyvät asiantuntijaruumiin pinnalle vioiksi, poikkeamiksi tai tavoiteltaviksi piirteiksi. 
Kun ruumiillisuuksiin liitetään toistuvasti tietynlaisia merkityksiä, merkityksistä tulee näiden ruumiillisuuksien ominaisuuksia (Ahmed 2004a), jolloin muodostuu vaikutelma pysyvästä ja normalisoidusta tasa-arvotyöntekijän ruumiillisuudesta. Merkitysten toiston myötä toistuvat myös merkityksiin kiinnittyneet affektit. Ne määrittävät, suuntaudutaanko lähemmäs vai kauemmas affektien merkitsemistä ruumiillisuuksista ja miten tavoiteltavina näitä ruumiillisuuksia tasa-arvotyössä pidetään. Kulttuurisiin ja historiallisiin merkityksenannon prosesseihin kietoutuneina ruumiillisina suuntautumisen tapoina (Ahmed 2007, 152-154; Paasonen 2017, 42) affektit heijastavat erilaisiin tasa-arvoasiantuntijan ruumiillisuuksiin kohdistuvia sosiaalisia normatiivisuuksia ja hierarkioita. Oikeanlainen, haluttava tasa-arvoasiantuntijan ruumis on siten mahdollista erottaa vääränlaisesta asiantuntijaruumiista ruumiillisuuksien affektiivisten kiinnittymisten pohjalta. Ruumiillisuus ja ruumiin piirteet eivät näin ole irrallaan työn käytännöistä, vaan ne merkityksellistyvät työtä määrittävinä, ehdollistavina ja mahdollistavina tekijöinä (Valkonen \& Valkonen 2014, 245).

Toisin kuin diskurssitaituruus (Brunila 2009), jolla viitataan oikeanlaisten puhetapojen ja usein keskenään ristiriitaisten tasa-arvotyön tavoitteiden ja diskurssien hallintaan, tasa-arvotyössä tarvittava affektitaituruus on affektien ja tunteiden hierarkian taitamista sekä kompetenssia analysoida ja neuvotella tasa-arvotyöhön liittyviä ristiriitaisia tunteita (Elomäki, Kantola, Koivunen \& Ylöstalo 2018). Affektitaituruus mahdollistaa pesäeron tekemisen radikaalina, poliittisena ja vihamielisenä näyttäytyvän feminismin ja professionaalin, yhteistyötä ja yhteistä etua korostavan asiantuntijatyön välille (Holli 2012; myös Ahmed 2012), ja sen tilanteisen taitamisen onkin nähty mahdollistavan tasa-arvotyössä ja -politiikassa erilaisia toimijuuden paikkoja (Brunila 2009, 154; Elomäki ym. 2018, 2).

Tasa-arvon edistäminen on usein kiistanalainen kysymys, ja se saattaa aiheuttaa myös vastustusta, vaikka tasa-arvo itsessään mielletään ihmisoikeuksien kaltaiseksi ja niihin rinnastettavaksi yhteiskunnalliseksi arvoksi (Ikävalko 2016). Tasa-arvoon yhteiskunnallisena arvona ja periaatteena on helppo sitoutua, sillä sen ei katsota edellyttävän konkreettisia tekoja tai oman toiminnan kriittistä arviointia (Ylöstalo 2019, 24). Koska feministisen toiminnan keskiössä on vallitsevien normatiivisten ja hegemonisten käytäntöjen kyseenalaistaminen, toiminta kuitenkin edellyttää toisinaan myös vaikeiden ja epämiellyttävien kysymysten esittämistä. Mielikuva vihaisesta ja hankalasta feminististä, joka pilaa muiden tunnelman astuessaan huoneeseen (Ahmed 2010), on kuitenkin voimakas eikä tasa-arvoasiantuntijapositiossa tästä syystä välttämättä haluta tai voida identifioitua feministiksi. Sen sijaan toimijat saattavat tavoitella ammatillista ja tunteellista viileyttä sekä neutraalia, lainsäädäntöön ja oikeanlaisten välineiden hallintaan nojaavaa asiantuntemusta (Elomäki ym. 2016), jossa tärkeinä pidettyjä asioita pyritään integroimaan hienovaraisesti pienin askelin ja hivutuksin osaksi laajempaa toimintaa. Affektitaituruus toimii siten myös eräänlaisena jaksamisen edellytyksenä helposti vastarintaa aiheuttavan ja uskottavuuspulan mahdollisuudesta kärsivän tasa-arvotyön tekemisen parissa (Brunila 2008; Ikävalko 2016).

Feministisen toiminnan - jolla tarkoitamme muun muassa kaksinapaisen sukupuolijärjestyksen ja sukupuoleen liittyvien hierarkioiden purkamista ja intersektionaalista, risteävät erot huomioivaa työtä - mahdollisuuksia avautuu tasa-arvotyössä melko satunnaisesti. Feministinen vastarinta paikantuu usein tasaarvotyötä tekevien keskuudessa syntyviin vapauden tiloihin ja keskinäiseen tukeen, joiden turvin hankaliakin asioita voidaan tuoda yhteiseen keskusteluun oman "piirin" ulkopuolelle. Tasa-arvotyössä liian feministiseksi tai näkökulmaiseksi tulkitun toiminnan kohtaama vastarinta muodostuu useimmiten vaikenemisesta eli siitä, että yhteistä keskustelua ei synny. Toisaalta myös tasa-arvotyötä tekevät osallis- 
tuvat tilanteisesti hiljaisuuksien tuottamiseen esittämällä tasa-arvo-ongelmat vakuuttavuuden nimissä näennäisen sukupuolineutraaleina tai varomalla aiheuttamasta sukupuoleen liittyvää konfliktia (Ikävalko \& Kantola 2017; Saari 2016), mikä usein johtuu pyrkimyksestä tehdä tasa-arvosta kaikkien yhteinen asia ja saavuttaa siihen liittyvä "yhteinen ymmärrys". Lisäksi lainsäädännön ja poliittisten ohjelmien velvoittamaa tasa-arvotyötä on Suomessa tehty pääosin vähäisin resurssein ja lyhytkestoisina projekteina työelämässä ja koulutuksessa. Tästäkin syystä näkökulmaisuuden välttely ja konsensushakuisuus ovat vaatineet erilaisten konfliktien ja jännitteiden piilottamista.

\section{Kuljeskeleva tutkimus affekteja sanoittamassa}

Aineistomme analysoinnissa sovellamme lukutapaa, jota kutsumme affektiivis-diskursiiviseksi (esim. Venäläinen 2017). Analyysia on ohjannut Sara Ahmedin (2004a; 2004b) ajatus tunteiden ja affektien sosiaalisesta ja tuottavasta luonteesta, mikä ohjaa huomion siihen, miten affektit, kiinnittyessään kulttuurisiin merkityksiin ja näiden merkitysten kiinnittyessä eri tavoin tasa-arvotyön subjekteihin ja objekteihin, tuottavat eron legitiimin ja ei-legitiimin tasaarvoasiantuntijuuden ja asiantuntijatiedon välille. Artikkelissa emme sijoita affektia ensisijaiseksi diskurssiin ja merkityksenantoon nähden tai niiden ulkopuolelle tai tee käsitteellistä eroa affektin ja tunteen (emootion) välille, sillä emme pidä affekteja emmekä tunteita kielestä ja merkityksenannon prosesseista erillisinä (esim. Ahmed 2004a; Probyn 2005; Wetherell 2012). Analyysi paikantuu historiallisesti aivan erityiseen ympäristöön ja avaamme seuraavaksi hieman aiheemme diskursiivista ja institutionaalista kontekstia.

Tutkimusaineisto on syntynyt kaksivuotisen tasa-arvo- ja yhdenvertaisuusasiantuntijakoulutuksen aikana. Koulutus toteutettiin osana Euroopan sosiaalirahaston rahoittamaa projektia, jonka tavoitteena oli alueellisen tasa-arvo- ja yhdenvertaisuusosaamisen ja -verkostojen luominen ja vahvistaminen eri puolilla Suomea sekä tasa-arvotyön integroiminen tulevan maakuntauudistuksen rakenteisiin. Projektissa oli mukana partneriverkosto, joka koostui kansalaisjärjestöistä, viranomaisista ja yliopistotoimijoista. Vastaavaa, tasa-arvo- ja yhdenvertaisuusosaamista yhdistävää ja alueellista tasa-arvotyötä vahvistamaan pyrkivää koulutusta ei Suomessa ollut aiemmin järjestetty.

Asiantuntijakoulutus rakentui kolmen sisällöllisen teema-alueen ympärille: tasa-arvoja yhdenvertaisuusosaaminen, yrittäjyysosaaminen sekä projektinhallintaosaaminen. Koulutus oli pilotti, ja siitä oli tarkoitus luoda tasaarvo- ja yhdenvertaisuuskoulutuksen malli, jota voisi toteuttaa eri muodoissa jatkossakin. Koulutukseen oli avoin haku, ja opiskelijavalinnassa huomioitiin muun muassa hakijoiden aikaisempi kokemus- ja motivaatiotaso, vuorovaikutus-, neuvottelu- ja yhteistyötaidot, kouluttajakokemus sekä kiinnostus toimia koulutuksen jälkeen alueellisena tasa-arvo- ja yhdenvertaisuusasiantuntijana. Koulutukseen haki 70 henkilöä, joiden joukossa oli muun muassa tutkijoita, viranomaisia, järjestötoimijoita, konsultteja sekä opetuksen ja viestinnän ammattilaisia. Hakijat olivat pääosin korkeasti koulutettuja. Koulutukseen valittiin 22 opiskelijaa eri puolilta Suomea.

Koulutus oli 40 opintopisteen laajuinen. Se koostui yhdeksästä kahden päivän lähitapaamisesta sekä opiskelijoiden itsenäisestä työskentelystä verkkoalustalla ja omissa maakunnissaan tapaamisten välillä. Koulutusprojektin työntekijät ja partnerijärjestöt tukivat opiskelijoiden itsenäistä työskentelyä koulutuksen eri vaiheissa. Lähitapaamisissa käsiteltiin alustusten ja ryhmätöiden avulla muun muassa sukupuolentutkimuksen teoriaa, lainsäädännön velvoitteita, tasa-arvo- ja yhdenvertaisuustyön välineitä, yritystoiminnan perusteita, asiantuntijuuden markkinointia ja brändäämistä sekä projektisuunnittelua ja rahoituksen hakemista. Lisäksi käytiin läpi opiskelijoiden omien tasa-arvoa ja yhdenvertaisuutta 
edistämään pyrkivien alueellisten projektien etenemistä. Vaikka jokaisella tapaamiskerralla oli oma teemansa, kulkivat jotkin aihealueet mukana läpi koko koulutuksen, osin myös opiskelijoiden tarpeista ja kiinnostuksen kohteista riippuen. Esimerkiksi neuvottelutaitoihin, verkostoitumiseen ja oman osaamisen tunnistamiseen ja sen markkinointiin kiinnitettiin huomiota läpi koko koulutuksen. Opiskelijat osallistuivat myös itse lähitapaamisten sisältöjen tuottamiseen kouluttamalla muita opiskelijoita oman osaamisensa pohjalta.

Koska kyseessä oli täydennyskoulutus, opiskelijoilta oletettiin projektin alusta alkaen kykyä hyvinkin itsenäiseen työotteeseen ja ryhtymistä tasa-arvo- ja yhdenvertaisuustyöhön tai vähintäänkin verkostojen luomiseen omalla alueellaan. Tämä tuntui mietityttävän osaa opiskelijoista ainakin koulutuksen alkuvaiheessa, sillä opiskelijoiden aiempi kokemus itsenäisestä asiantuntijatyöstä ja sen sisällöstä vaihteli. Joillakin koulutukseen osallistuneilla oli vahva sukupuolentutkimuksen osaaminen, muttei niinkään kokemusta kehittämistyöstä tai poliittisesta vaikuttamisesta; osalla oli kehittämis- ja projektityön osaamista, mutta tasa-arvo- ja yhdenvertaisuustyön käsitteistö saattoi olla vieraampaa.

Varsinainen tasa-arvo- ja yhdenvertaisuusosaaminen käsitettiin projektissa pitkälti lainsäädännön (tasa-arvo- ja yhdenvertaisuuslait) velvoitteiden sekä erilaisten työvälineiden, kuten sukupuolivaikutusten arvioinnin, tasaarvo- ja yhdenvertaisuussuunnittelun ja osallistavien pedagogisten menetelmien, hallitsemisena. Lisäksi projektissa mukana olleet partnerit painottivat kukin oman toimintaalueensa ja tavoitteidensa mukaisia sisältöjä. Työote oli kehittämisorientoitunut ja esimerkiksi sukupuolentutkimuksen teoreettisen osaamisen vahvistaminen ei varsinaisesti ollut koulutuksen keskiössä, vaikka joitakin käsitteellistyksiä käytettiin työskentelyn tukena. Tärkeimpänä pidettiin käsitteiden soveltamista käytännön työhön. Joistakin teoreettisista käsitteellistyksistä käytettiin niiden popula- risoituja muotoja, kuten sukupuolisensitiivisyys, sukupuolen moninaisuus tai kulttuurisensitiivisyys.

Artikkelin tutkimusaineisto koostuu kuuden asiantuntijakoulutuksen opiskelijan haastatteluista ${ }^{1}$ (yhteensä 41 sivua), jotka tehtiin syksyllä 2017 sekä kolmentoista opiskelijan oppimispäiväkirjoista, joissa he pohtivat tasaarvo- ja yhdenvertaisasiantuntijuutensa rakentumista. Näiden rinnalla luemme havaintomuistiinpanojamme, joita olemme tehneet projektin seitsemässä lähitapaamisessa sekä työryhmien kokouksissa keväästä 2017 alkusyksyyn 2018.

Aineiston tuotanto oli osallistuvaa ja kuljeskelevaa (Ikävalko \& Kurki 2014; Kurki, Ikävalko \& Brunila 2016). Olemme osallistuneet eri tavoin aineiston rakentumiseen, koska olemme työskennelleet projektissa ja olleet suunnittelemassa ja toteuttamassa asiantuntijakoulutusta. Olemme esimerkiksi osallistuneet projektin partnereista koostuvan työryhmän, jossa suunniteltiin koulutuksen lähitapaamisten sisältöjä, työhön. Lisäksi olemme tukeneet opiskelijoita itsenäisessä työskentelyssä, antaneet palautetta lähitapaamisen välillä tehdyistä tehtävistä ja toimineet kouluttajina lähitapaamisissa.

Kuljeskeleva aineiston tuottaminen (Ikävalko 2016) viittaa tässä artikkelissa etenkin siihen, että tutkimusaihetta koskevaan tietämiseemme on vaikuttanut "virallisen" aineistomme lisäksi siihen kietoutuva "epävirallinen" (kokemus)tietomme projektin kulusta, ihmisten välisistä suhteista ja ilmapiireistä esimerkiksi koulutustilanteissa. Kokemuksiamme on mahdotonta erottaa virallisesta tutkimusaineistosta ja siksi aineistomme on kokonaisuudessaan paljon laajempi, monisyisempi ja epämääräisempi kuin edellä mainitut haastattelut ja havaintomuistiinpanot. Olemme myös osaltamme vastuussa siitä, millaiseksi projekti kokonaisuudessaan muodostui ja olemme reflektoineet omaa osallisuuttamme siinä osana aineiston analyysia. Tutkimusaihetta koskeva tietämyksemme ja tulkintamme on rakentunut myös historiallisesti ja omien aikaisem- 
pien kokemustemme kautta, sillä luemme artikkelissa aineistoa väistämättä aiemmasta tasa-arvotyöstä muodostuneiden kokemustemme, muistojemme ja tunnelmiemme läpi (Ikävalko 2016; St. Pierre 1997). Esimerkiksi koulutuksessa käsitellyt tasa-arvo- ja yhdenvertaisuustyössä kohdatut vastarinnan muodot ja niihin liittyvät henkilökohtaisen epäonnistumisen tunteet olivat meille tuttuja ja tunnistettavia.

\section{Tasa-arvoasiantuntijuuden affektiivinen myyntityyli}

Keskeistä palvelutalouden asiantuntijatyössä on kokemusten ja niihin kytkeytyvien mielikuvien tuottaminen (Valkonen \& Valkonen 2014, 244). Koulutuksen aikana asiantuntijuutta vahvistavia ja etäännyttäviä merkityksiä työstettiin eri näkökulmista. Keskeistä oli, millaisten asioiden katsottiin tuovan tuoreelle, uransa alkuvaiheessa olevalle tasa-arvo- ja yhdenvertaisuusasiantuntijalle työssä tarvittavaa uskottavuutta. Tämä keskustelu käynnistyi heti koulutuksen alkumetreillä, sillä osana koulutusta opiskelijoiden tuli tarjota asiantuntijuuttaan kotimaakuntiensa maakuntaohjelmien valmistelutyöhön. Haastatteluissa opiskelijat puhuvat tavoiteltavasta ja toivotunlaisesta tasa-arvoasiantuntijuudesta neutraalina asiantuntijatietona, jota vasten 'vääränlainen' asiantuntijuus saa merkityksen näkökulmaisena ja poliittisena:

Et siis pitää olla tietopohja, ymmärrys ja kyllä mun mielestä asiantuntijuuteen liittyy myös se, että oot asiantuntija etkä pelkästään semmosen aatteellisen yhdistyksen toimija. Et tavallaa semmonen ammatillinen taso. Et tavallaa ei voi tehä sitä hommaa vaan ideologisella tasolla. (Haastattelu 4, syksy 2017)

Tulkitsemme tämän kantaaottamattomuuden ja epäpoliittisuuden ajatuksen kulttuuriseksi vaatimukseksi kiinnittyä tiettyihin tasa-arvoasiantuntijuutta ja asiantuntijan ideaaliruumista koskeviin merkityksiin ja ottaa etäisyyttä toisista (esim. Ahmed 2004a, 2010; myös Berlant
2011). Asiantuntijaksi nimeämisen ja asiantuntijuuden oikeutuksen saaminen edellyttää poliittisen aktivismin leimaamista ei-tavoiteltavaksi ja näkökulmaiseksi; asiantuntijuutta legitimoidaan pikemminkin suhteessa asiakaskuntaan ja sen tarpeisiin. Tunteellisuuden ja henkilökohtaisuuden nähdään tekevän asiantuntijoista epäuskottavia, kun taas itsestä irrallaan olevan tiedon tuomaan auktoriteettiin vetoaminen sekä tekninen tasa-arvo- ja yhdenvertaisuuspuhe lainsäädännön vaatimuksista sekä kehittämisen työvälineistä merkitsevät uskottavuutta. Tavoitteena on eräänlainen neutraali asiantuntijuus, erotuksena poliittisesti sitoutuneesta toiminnasta:

Niin ehkä se ammatillisuus tulee esiin siinä, että toimiessa tasa-arvoasiantuntijana, me aidosti otetaan kaikki eri ihmisryhmät huomioon eikä haeta vaan jonku tietyn ihmisryhmän etua, niinku siinä tasa-arvoasiantuntijan tittelillä. Riippumatta siitä omasta henkilökohtaisesta taustasta, liittyi se sitten omaan seksuaaliseen suuntautumiseen tai sukupuoleen tai uskontoon tai vaikka vammaisuuteen. (Haastattelu 3, syksy 2017)

Poliittisen neutraaliuden lisäksi palvelutalouden kontekstissa tasa-arvoasiantuntijaksi tuleminen merkitsee yrittäjämäisen affektiivisen tyylin omaksumista. Tyylin mukaisesti asiantuntija hyväksyy olevansa itse itsensä tärkein pääoma tasa-arvon ja yhdenvertaisuuden markkinoilla ja suhtautuu halukkaasti tämän pääomansa ja siihen kuuluvan affektitaituruuden kehittämiseen. Itsen kilpailukykyisenä pitäminen edellyttää sisäänpäin kääntymistä (esim. Lahikainen \& Harni 2016; Brunila \& MononenBatista Costa 2010) ja oman toiminnan jatkuvaa reflektointia ja muokkaamista. Tämän seurauksena asiantuntijakoulutettavat tuntevat yhteistyöverkostoista ja kollektiivisesta tuesta huolimatta olevansa yksin vastuussa asiantuntijabrändinsä ja -olemuksensa houkuttelevuudesta. Tämä palvelutalouden projektimuotoiselle asiantuntijatyölle tyypillinen ikuinen keskeneräisyyden tunne (esim. Brunila 2009) näkyy myös siinä, miten opiskelijat puhuvat haas- 
tatteluissa vaatimuksesta asiantuntijuuden jatkuvaan kehittämiseen:

Mut yks tosi tärkee osa asiantuntijuutta on se itsereflektiokyky ja ne itsereflektiotaidot. Että se jatkuva työ oman itsensä kanssa. Ja jotenki niinku se vastuun ottaminen omasta itsestä. (Haastattelu 3, syksy 2017)

Tasa-arvo- ja yhdenvertaisuus ammattina ja siinä vaadittava osaaminen eivät juuri eroa muista palvelutyön asiantuntija-ammateista ja niissä vaadituista taidoista (Brunila 2009, 23-24). Erona muuhun asiantuntijatyöhön on kuitenkin se, että tasa-arvo- ja yhdenvertaisuusasiantuntijan myymä tuote, hänen henkilökohtainen brändinsä, kohtaa toistuvaa kyseenalaistamista ja vastustusta. Tästä syystä myönteisinä pidettyjen affektien vahvistamisesta ja negatiivisten affektien ja tunneilmaisujen vaientamisesta tulee olennainen osa asiantuntijuutta. Erityisesti negatiivisuuteen ja liialliseen henkilökohtaisuuteen viittaavat affektit näyttäytyvät koulutuksessa ei-toivotussa valossa:

Ammatillisuus on sitä, miten mä toimin. Asiantuntijuus on aiheen hallinta ja se, mitä tekee, ammatillisuus sitä, miten tekee. Meidän työssämme meidän täytyy miettiä, mikä on se meidän eettinen ympäristö, riippumatta meidän omista tuntemuksista, meidän täytyy siinä ympäristössä toimia ammatillisesti, koska meillä on se ammattitaito. Et välillä se on sitä, et pitää vetää henkeä tai vaikka poistua huoneesta. (Havaintomuistiinpanot, syksy 2017)

Vaatimus affektien ja tunneilmaisujen kulttuurisen hierarkian sujuvalle taitamiselle on ominaista tasa-arvotyön kaltaisessa asiantuntijatyössä, jossa erilaisetjännitteet ja konfliktit ovat arkipäiväisiä ja jossa asiantuntijan pyrkimykset kohtaavat jatkuvaa vastustusta. Tunnistimme tämän vastarintaan varautumisen myös itse toimiessamme tulevien asiantuntijoiden kouluttajina. Halusimme varustaa opiskelijoita tiedoilla erilaisista vastarinnan strategioista ja luoda mahdollisuuksia vastustuksen ja siitä lähes väistämättä seuraavan epäonnistumi- sen tunteen käsittelemiseen osana koulutusta. Negatiivisten affektien vaientaminen voidaan nähdä myös keinona oman itsen etäännyttämiseen ja irrottamiseen myytävästä tuotteesta sekä tasa-arvotyölle ja feministiselle toiminnalle leimallisesta tunteellisen kokemusasiantuntijan roolista (esim. Elomäki ym. 2016). Itsen suojelun vaatimus on korostunut palvelutalouden yrittäjähenkisessä kontekstissa, jossa asiantuntijatyötä tehdään affektiivisesti omalla ruumiilla ja jossa myös riski epäonnistumisesta kannetaan yksin:

Se, että ku se on itsestäänselvää et tulee sitä vastarintaa, nii se, että pystyy suhtautuu siihen ammatillisesti ja tota löytämään niitä keinoja, miten päästään niistä tilanteista eteenpäin, ilman että tulee sitä turhautumista. (Haastattelu 2, syksy 2017)

Asiantuntijan uskottavuuden kannalta olennaista on, miten hän onnistuu ilmaisemaan ruumiillisella olemuksellaan tuotteen mukaista affektiivista tunnelmaa ja ilmettä (Valkonen 2011, 105, Sharpeen 2005 viitaten). Tuotteeseen liitettävät merkitykset vaikuttavat siihen, miten sitä myydään ja millainen asiantuntijan affektiivinen tyyli näyttäytyy uskottavana (Valkonen \& Valkonen 2014, 245, Alleniin \& du Gayhin 1994 viitaten). Tasa-arvoasiantuntijuus ei siten tarkoita yksinomaan tuotteen tai palvelun myymistä vaan tuotteesta ja palvelusta luotujen oikeanlaisten affektiivisten vaikutelmien muodostamista. Tässä vaikutelmien muodostamisessa tasa-arvoasiantuntijan ja asiakkaan välinen joustava ja jännitteetön, mahdollisen konfliktin tukahduttava vuorovaikutus on keskeisessä roolissa ja itsessään osa myytävää tuotetta:

Täytyy osata motivoida muita ihmisiä ja pitää osata myydä, niin se asia kuin myös silleen itteensä. (Ryhmäkeskustelu 1, syksy 2017)

Se tasa-arvoasiantuntijuus on tilannetajua, kestävyyttä ja semmosta epämukavuuden sietämistä. Täytyy osata antaa toisille tilaa, ei saa olla besserwisser, vaan antaa muille tilaa 
ymmärtää. Sit pitää olla semmosta tilannetajua ja ymmärrystä siitä, mikä on ihmisten tietämystaso. Ja semmosta et aistii sen tunnelman. (Ryhmäkeskustelu 2, syksy 2017)

Tasa-arvoasiantuntijuuden subjektiksi tuleminen edellyttää tiettyihin tasa-arvoasiantuntijuuden kulttuurisiin merkityksiin ja tietämisen positioihin kiinnittymistä ja niistä käsin toimimista (Naskali 2011; Venäläinen 2017, 8). Aineistossamme tätä tasa-arvotyön oikein tekemistä tulkitaan kokeneiden asiantuntijoiden toimintaa seuraamalla ja imitoimalla, minkä ajatellaan antavan vihjeitä siitä, millaista tekemisen tapaa kannattaa tavoitella (esim. Nikunen 2013, 25). Opiskelijat havainnoivat kokeneempien kouluttajien tyyliä tarkasti ja koulutuksen lähitapaamisissa kouluttajilta kysyttiin vinkkejä vaikeista tilanteista selviämiseen. Kun kokenut tasa-arvoasiantuntija oli mukana opiskelijoiden solmiessa kontakteja kotimaakunnissaan, hänen rentoon ja huolettomuutta tavoittelevaan kanssakäymisen tapaansa kiinnitettiin vähintään yhtä paljon huomiota kuin argumenttien sisältöön. Myös asiakkaan ja tämän toimintaympäristön tuntemuksella sekä etukäteen harjoiteltujen tekniikoiden ja strategioiden tilanteisella taitamisella on merkittävä rooli asiantuntijuudelle:

Mut sit muuten se semmonen et miten harjoitella semmosia asioita, jotka liittyy semmosiin kohtaamisiin. Et sulle tulee semmonen tietämys, mitä ja millasia taktiikoita kannattaa käyttää ja mitä kenenki kanssa ja missä tilanteessa, jotta se viesti menee perille. Ja siin kohtaamises on tärkeetä semmonen, et hahmottaa sen kohdeyleisön, niinku et ketä ne on, mitä ne jo tietää, mitä ei, mitä ne tekee ja miten eri asiat siinä työssä vaikuttaa ja näyttäytyy. Et sit voi vähän ehkäistä sitä, ettei ne ihmiset käänny sua ja sitä asiaa vastaan. (Haastattelu 5, kevät 2018)

Vastaväitteiden hallitseminen ja tilanteeseen sopiva affektiivinen tyyli on eräänlainen affektiivinen investointi (esim. Gregg 2010), jota oikeanlaiseksi tasa-arvoasiantuntijaksi tulemi- nen edellyttää ja jota vasten asiantuntijakoulutettavat peilaavat toimintaansa. Tämän ajatellaan mahdollistavan ja monipuolistavan tasa-arvo- ja yhdenvertaisuustyössä tarvittavia ja vaihtuviin tilanteisiin sopivia toimijan paikkoja (Brunila 2009, 154).

\section{Johtopäätökset}

Projektimuotoisessa tasa-arvoasiantuntijakoulutuksessa tuotettuun ideaaliasiantuntijuuteen liittyy miellyttävän, kitkattoman, palvelu- ja markkinahenkisen asiakaskokemuksen tarjoaminen ja myyminen. Projektimuotoisessa koulutuksessa tasa-arvo- ja yhdenvertaisuusasiantuntijaksi tullaan omaksumalla oikeanlainen affektiivinen tyyli. Tässä tyylissä tasa-arvoon liittyvien ongelmien esille nostaminen ja ratkaiseminen jäävät toissijaiseksi asiantuntijan oman itsen kautta välittyvälle affektiiviselle kokemukselle; säröttömälle, jatkuvalle ja jouhevalle vuorovaikutukselle ja epävarmuuden tunteiden peittämiselle sekä erilaisten tekniikoiden ja argumenttien taitamiselle.

Tulkintamme mukaan tasa-arvo- ja yhdenvertaisuustyön menetelmien ja tekniikoiden avulla asiakastilanteisiin voidaan luoda henkilökohtaisuuden ja autenttisuuden tuntua. Koska tekniikat ja argumentit ovat ennalta opeteltuja ja niiden pääasiallinen tavoite on varmistaa, että vuorovaikutus on sujuvaa ja kitkatonta, on kuitenkin mahdollista, että toiminnan tavoitteista joustetaan liikaa. Työkalut ja välineet kyllä tuovat tasa-arvotyölle sen kaipaamaa legitimiteettiä, mutta samanaikaisesti ne häivyttävät työn poliittista muutosvoimaa ja piilottavat siihen sisältyvän konfliktin mahdollisuuden (esim. Ahmed 2007; Ikävalko 2016; Saari 2013). Palvelutalouden markkinahenkisessä tasa-arvotyössä, jossa oikeanlaisen ilmapiirin luominen ja ylläpitäminen on olennaista, tasa-arvo ja tasa-arvotyön tavoitteet asettuvat jatkuvan taivuttamisen ja neuvottelun alaisiksi. Vaatimus tulkita muiden toiminnasta, mihin tasa-arvotyön ja -asiantuntijuuden tekemisen tapaan kannattaa sijoittaa ja 
mistä ottaa etäisyyttä, on korostunut palvelutalouden ruumiillisessa asiantuntijatyössä (Ahmed 2010; Nikunen 2013, 18, 25).

Vuorovaikutuksen sujuvuuden korostaminen johtaa lisäksi siihen, että oikeanlainen tasa-arvotyön tekemisen tapa näyttäytyy ristiriidattomana ja objektiivisena, siinä missä kriittisten huomioiden tekeminen puolestaan tulkitaan tunnelman pilaamisena, ja niiden esittäjä leimataan hankalaksi (Ikävalko \& Brunila 2011, 330; myös Ahmed 2010). Tulostemme pohjalta pohdimme, onko palvelutalouden ja markkinahenkisen tasa-arvoasiantuntijuuden ensisijainen tavoite sittenkään tasa-arvoon liittyvän ongelman ratkaiseminen vai vuorovaikutuksen sujuvuus ja konfliktittomuus. Onko tuote, jota myydään, sujuva vuorovaikutus?

Koulutuksen projektimuotoisella toteuttamistavalla oli seurauksensa. Projektimuotoiseen toimintaan kuuluvat eteenpäin menemisen, tulosten saavuttamisen ja kehityksen ihanteet. Nämä ihanteet sekä rahoittajan harjoittama arviointi suuntasivat koulutuksen toteuttajien pyrkimyksiä kohti turvallisia, "hyviksi havaittuja" menetelmiä, lainsäädännön tavoitteissa pitäytymistä sekä projektin osallistujien eli opiskelijoiden menestymisen varmistamista.

Tulkintamme mukaan koulutuksessa tuotettiin käsitystä neutraalista tasa-arvo- ja yhdenvertaisuusasiantuntijuudesta, joka osoittautui valkoiseksi, binaarisesti sukupuolittuneeksi tasa-arvofeminismiksi. Asiantuntijan ei-valkoisuus, ei-heteroseksuaalisuus, kahtiajakoa rikkova sukupuoli, ja näihin ruumiillisuuksiin kiinnittyminen näyttäytyvät puolestaan lähtökohtaisesti värittyneinä, henkilökohtaisina ja poliittisina ja siten epäammattimaisina. Tämä ei koske yksinomaan tasa-arvoja yhdenvertaisuustyön tavoitteita, vaan kiinnittyy affektiivisesti myös asiantuntijan tyyliin (Ahmed 2004a). Tässä tyylissä esimerkiksi kiihtymistä ja muita henkilökohtaisuuteen ja poliittisuuteen liittyviä affekteja ja niiden esille tuomista tulee välttää, sillä nämä nähdään uskottavuutta heikentävinä vikoina, puutteina ja poikkeamina. Neutraalius, affektiivinen tasai- suus, on puolestaan ideaaliasiantuntijatiedon ja -ruumiillisuuden mitta, joka määrittää asiantuntijan kelpoisuutta (Lahikainen \& Harni 2016, 34). Väitämme, että tasa-arvoasiantuntijan markkina- ja yrittäjähenkinen, neutraali tyyli (vrt. Kinnunen \& Parviainen 2016) kiinnittää myönteisyyden ja ammatillisen viileyden affektiivisesti tietynlaisiin asiantuntijan ruumiillisuuksiin - ruumiillisuuksiin, joihin kaikilla ei ole pääsyä. Samanaikaisesti neutraaliuden vaatimus hämärtää sukupuoleen ja muihin eroihin kiinnittyvät, eriarvoisuutta tuottavat vallan hierarkiat muuttamalla ne asiantuntijan henkilökohtaisiksi ansioiksi ja puutteiksi (Ikävalko 2016, 24-28; Mäkinen 2012; myös Scharff 2016, 113).

Koulutuksen eräänä tavoitteena oli luoda opiskelijoille edellytyksiä työllistää (itse) itsensä tasa-arvon ja yhdenvertaisuuden markkinoilla, mikä osaltaan selittänee etäisyyden ottamisen radikaaliin feministiseen toimintaan. Tasa-arvotyön markkinoitumisesta ja kaupallistumisesta ei kuitenkaan koulutuksen aikana käyty yhteistä keskustelua vaan se otettiin annettuna kehyksenä, jonka puitteissa asiantuntija työskentelee. Erilaisten feministisen vastarinnan ja epäkaupallisten, vähemmän konformististen toimintamuotojen esiin nostaminen olisi ehkä antanut tilaa moninaisemmille affektiivisille tyyleille. Tutkimuksemme tulokset osoittavat, että koska markkinalähtöisen tasa-arvo- ja yhdenvertaisuustyön näkökulmasta asiantuntijan tulee pystyä tarjoamaan palvelujaan mahdollisimman laajalle asiakaskunnalle, liian näkökulmaisena ja radikaalina näyttäytyvä affektiivinen tyyli vaarantaa koulutettavien tulevan asiantuntija-aseman. Asiantuntijan näyttäytyessä pehmeänä, henkilökohtaisten mieltymysten ja arvojen ohjaamana, näyttäytyy myös tasa-arvo sellaisena: näkökulmaisena ja kiisteltynä; subjektiivisena ja henkilökohtaisena (Ahmed 2007, 247). Poliittisten sidonnaisuuksien välttäminen ja neutraaliuden tavoitteleminen sen sijaan antavat lupauksen (Berlant 2011) oikeanlaisen tasa-arvoasiantuntija-aseman saavuttamisesta. 


\section{Viitteet}

1 Helsingin yliopiston kasvatustieteellisen tiedekunnan opiskelija Reetta Kiukainen teki haastattelut osana pro gradu -tutkielmaansa (https:// helda.helsinki.fi/handle/10138/277572).

\section{Kirjoittajat}

Anna Mikkola, KM, tohtorikoulutettava, Helsingin yliopisto, sähköposti: aninmikk@gmail.com

Elina Ikävalko, FT, tutkijatohtori, Helsingin yliopisto, sähköposti: elina.ikavalko@helsinki.fi

Kristiina Brunila, FT, apulaisprofessori, Helsingin yliopisto, sähköposti: kristiina.brunila@helsinki.fi

\section{Kirjallisuus}

Ahmed, S. (2004a) The Cultural Politics of Emotion. New York: Routledge.

Ahmed, S. (2004b) Affective economies. Social Text 22 (2), 118-139.

Ahmed, S. (2007) The language of diversity. Ethnic and Racial Studies 30 (2), 235-256.

Ahmed, S. (2010) The Promise of Happiness. Durham: Duke University Press.

Ahmed, S. (2012) On Being Included: Racism and Diversity in Institutional Life. Durham: Duke University Press.

Berlant, L. (2011) Cruel Optimism. Durham: Duke University Press.

Brunila, K. (2008) Hivutuksia, hanttiinpistämisiä ja muita diskurssitaituruuksia - Toimijuus sukupuolten välistä tasa-arvoa koskevassa tasa-arvotyössä. Teoksessa H. Ojala, T. Palmu \& J. Saarinen (toim.) Sukupuoli ja toimijuus koulutuksessa. Tampere: Vastapaino, 71-98.

Brunila, K. (2009) Parasta ennen. Tasa-arvotyön projektitapaistuminen. Kasvatustieteen laitoksen tutkimuksia 222. Helsinki: Helsingin yliopisto.

Brunila, K. \& Mononen-Batista Costa, S. (2010) Tiedon, työllisyyden, osaamisen, yrittäjyyden ja tasa-arvon eurooppalainen Suomi. Teoksessa K. Komulainen, S. Keskitalo, M. Korhonen \&
S. Lappalainen (toim.) Yrittäjyyskasvatus hallintana. Tampere: Vastapaino, 207-230.

Elomäki, A., Kantola, J., Koivunen, A. \& Ylöstalo, H. (2016) Kamppailu tasa-arvosta: tunne, asiantuntijuus ja vastarinta strategisessa valtiossa. Sosiologia 53 (4), 257-275.

Elomäki, A., Kantola, J., Koivunen, A. \& Ylöstalo, H. (2018) Affective virtuosity: Challenges for governance feminism in the context of the economic crisis. Gender, Work \& Organization 26 (6), 822839.

Gregg, M. (2010) Working with affect in the corporate university. Teoksessa S. Paasonen \& M. Liljeström (toim.) Working with Affect in Feminist Readings: Disturbing differences. Lontoo: Routledge, 182-192.

Henriksson, L. \& Wrede, S. (2004) (toim.) Hyvinvointityön ammatit. Helsinki: Gaudeamus.

Holli, A. M. (2003) Discourse and Politics for Gender Equality in Late Twentieth Century Finland. Acta Politica 23. Helsinki: Helsingin yliopisto.

Holli, A. M. (2012) Kriittisiä näkökulmia tasa-arvon tutkimukseen. Teoksessa J. Kantola, K. Nousiainen \& M. Saari (toim.) Tasa-arvo toisin nähtynä. Oikeuden ja politiikan näkökulmia tasa-arvoon ja yhdenvertaisuuteen. Helsinki: Gaudeamus, 73-96.

Holli, A. M. \& Kantola, J. (2007) State feminism Finnish style: Strong policies clash with implementation problems. Teoksessa J. Outshoorn \& J. Kantola (toim.) Changing State Feminism. New York: Palgrave, 82-101.

Ikävalko, E. (2016) Vaikenemisia ja vastarintaa: Valtasuhteet ja toiminnan mahdollisuudet oppilaitosten tasa-arvosuunnittelussa. Helsinki: Helsingin yliopisto.

Ikävalko, E. \& Brunila, K. (2011) Tasa-arvosuunnittelu managerialistisen hallinnan tekniikkana. Sosiologia 48 (4), 323-337.

Ikävalko, E. \& Kurki, T. (2014) Tutkimuksen rajoilla kuljeskellen. Teoksessa K. Brunila \& U. Isopahkala-Bouret (toim.) Marginaalin voima! Aikuiskasvatuksen 51. vuosikirja. Helsinki: Kansanvalistusseura ja Aikuiskasvatuksen tutkimusseura, 222-241.

Ikävalko, E. \& Kantola, J. (2017) Feminist resistance and resistance to feminism in gender equality planning in Finland. European Journal of Women's Studies 24 (3), 233-248.

Julkunen, R. (2017) Muuttuvat hyvinvointivaltiot. Eurooppalaiset hyvinvointivaltiot reformoitavina. Jyväskylä: Jyväskylän yliopisto, SoPhi. 
Kantola, J. \& Squires, J. (2012) From state feminism to market feminism? International Political Science Review 33 (4), 382-400.

Kinnunen, T. \& Parviainen, J. (2016) Rekrytointikonsulttien tuntuma "hyvästä tyypistä". Teoksessa J. Parviainen, T. Kinnunen \& I. Kortelainen (toim.) Ruumiillisuus ja työelämä - Työruumis jälkiteollisessa taloudessa. Tampere: Vastapaino, 59-75.

Kurki, T., Ikävalko, E. \& Brunila, K. (2016) Nomadinen tutkimus, kirjoittaminen ja tutkijuus. Aikuiskasvatus 36 (2), 127-130.

Lahikainen, L. \& Harni, E. (2016) Yrittäjämäinen ruumis jälkiteollisessa palvelutaloudessa. Teoksessa J. Parviainen, T. Kinnunen \& I. Kortelainen (toim.) Ruumiillisuus ja työelämä - Työruumis jälkiteollisessa taloudessa. Tampere: Vastapaino, 26-39.

Mannevuo, M. (2015) Affektitehdas. Työn rationalisoinnin historiallisia jatkumoita. Annales Universitatis Turkuensis C 406. Turku: Turun yliopisto.

Mazur, A. G. \& McBride Stetson, D. (1995) (toim.) Comparative State Feminism. Thousand Oaks: Sage.

Mäkinen, K. (2012) Becoming Valuable Selves: SelfPromotion, Gender and Individuality in Late Capitalism. Acta Universitatis Tamperensis 1732. Tampere: Tampereen yliopisto.

Naskali, P. (2001) Sukupuoli ja ruumiillisuus opetuksellisessa vuorovaikutuksessa. Naistutkimus 14 (3), 4-15.

Nikunen, M. (2013) Affektiivinen opetustyö yliopistossa: pätkätyöläisten kokemuksia. Naistutkimus 26 (4), 17-29.

Paasonen, S. (2017) Affekti suhteena ja intensiteettinä. Tieteessä tapahtuu (2), 42-43.

Parviainen, J. (2011) Työn uusi ruumilllisuus. Liikunnanohjaajien keho työvälineenä ja performatiivisuuden pakko palvelutyössä. Työelämän tutkimus 9 (3), 207-223.

Pedwell, C. \& Whitehead, A. (2012) Affecting feminism: Questions of feeling in feminist theory. Feminist Theory 13 (2), 115-129.

Probyn, E. (2005) Blush. Faces of Shame. Minneapolis: University of Minnesota Press.
Raevaara, E. (2005) Tasa-arvo ja muutoksen rajat. Sukupuolten tasa-arvo poliittisena ongelmana Ranskan parité- ja Suomen kiintiökeskusteluissa. Helsinki: Tasa-arvoasiain neuvottelukunta, Sosiaali- ja terveysministeriö.

Saari, M. (2013) Promoting gender equality without a gender perspective: Problem representations of equal pay in Finland. Gender, Work and Organization 20 (1), 36-55.

Saari, M. (2016) Samapalkkaisuus - neuvoteltu oikeus. Naisten ja miesten palkkaeriarvoisuus poliittisena ja oikeudellisena kysymyksenä korporatistisessa Suomessa. Valtiotieteellisen tiedekunnan julkaisuja 25. Helsinki: Helsingin yliopisto.

Scharff, C. (2016) The psychic life of neoliberalism: Mapping the contours of entrepreneurial subjectivity. Theory, Culture \& Society 33 (6), 107-122.

St. Pierre, E. A. (1997) Methodology in the fold and the irruption of transgressive data. Qualitative Studies in Education 10 (2), 175-189.

Valkonen, J. (2011) Aineettoman palvelutuotannon materiaalisuus. Tutkimus kaupallisen luontomatkailun palvelutyöstä. Työelämän tutkimus 9 (2), 105-119.

Valkonen, J. \& Valkonen, S. (2014) Uskottavat safariruumiit: sukupuoli ja ruumiillisuus palvelutuotetaitoina Lapin safariturismissa. Työelämän tutkimus 12 (3), 244-256.

Venäläinen, S. (2017) Affektiivisuus ja diskursiivisuus. Identiteettityötä ja kevytkenkäisyyttä eri suuntausten rajapinnoilla. Sukupuolentutkimus (1), 82-85.

Wetherell, M. (2012) Affect and Emotion: A New Social Science Understanding. Lontoo: Sage Publications.

Ylöstalo, H. (2012) Tasa-arvotyön tasa-arvot. Acta Electronica Universitatis Tamperensis 1152. Tampere: Tampereen yliopisto.

Ylöstalo, H. (2019) Mitä tasa-arvoasenteet kertovat tasa-arvosta? Teoksessa M. Teräsaho \& J. Närvi (toim.) Näkökulmia sukupuolten tasa-arvoon - analyyseja tasa-arvobarometrista 2017. Helsinki: Terveyden ja hyvinvoinnin laitos (THL), 17-31. 